\title{
MENGENAL SISTEM GNOTOBIOTIK DAN PERANANNYA PADA BUDIDAYA BIOTA LAUT
}

\author{
Oleh \\ Marenda Pandu Rizqi ${ }^{1)}$
}

\begin{abstract}
INTRODUCTION TO GNOTOBIOTICS AND ITS ROLE IN MARICULTURE. Initial colonization of microbial community in marine larvae is one of the important stage in larval development in terms of subsequent growth, immunostimulation, and pathogen elimination. Gearing towards environmentally sustainable manner of aquaculture, early microbial manipulation in larval stage may provide an alternative in efficient and productive larviculture. One of the tool to further study the host-microbe interaction is through in-vivo culture of axenic and gnotobiotic larvae, in which a germ-free larvae was produced, and subsequently induced with single strain benign microbe to observe its response and characteristics. Several methods and protocols to obtain axenic-gnotobiotic condition is highlighted, along with the current development of gnotobiotic research, particularly in commercially valuable saltwater fish, e.g. Atlantic cod and European seabass. The development of novel gnotobiotic protocols combined with different scientific approach, e.g. gene expression, quorum sensing, immunostimulants, and purified diets may provide better insight in host-microbe interaction of marine biota, which in turn will benefit the implementation of specific probiotics, prebiotics, diets, and microbial regulation in marine larviculture.
\end{abstract}

\section{PENDAHULUAN}

Pengetahuan mengenai biota laut terus mengalami perkembangan, revisi, bahkan paradigma baru yang dinamis seiring dengan semakin majunya sains dan teknologi kelautan. Informasi terkini mengenai biota laut berperan penting dalam meningkatkan produktivitas pada bidang-bidang terapannya seperti bioteknologi dan budidaya biota laut. Salah satu bahasan yang kini menjadi perhatian yaitu mengenai hubungan/ interaksi antara biota laut sebagai inang dan mikroorganisme di dalamnya. Pada fase larva sampai juvenil, kelangsungan

\footnotetext{
${ }^{1)}$ Loka Konservasi Biota Laut Bitung - LIPI
}

hidup biota laut banyak dipengaruhi oleh komunitas mikroorganisme yang menempel dan berkembang di saluran pencernaan maupun di organ-organ lainnya (Vadstein et al., 2013). Selain itu mikroorganisme yang hidup dan berkembang di air laut juga mempunyai peranan yang penting dalam menentukan sintasan, pertumbuhan, maupun respon imun biota tersebut (Gatesoupe, 1999; Perez et al., 2010). Fase awal perkembangan hidup biota menjadi masa-masa kritis pada kegiatan budidaya karena mempunyai risiko paling tinggi terjadinya infeksi patogen dan penyakit, 
terganggunya pertumbuhan, bahkan kematian massal (Attramadal et al., 2012; Vadstein et al., 2013; Bentzon-Tilia et al., 2016).

Studi mengenai mikroorganisme dan biota laut telah banyak dilakukan, namun kompleksitas interaksi antara biota inang, mikroorganisme, dan lingkungannya menyebabkan sulitnya memahami, mengontrol, maupun memanipulasi interaksi ini untuk mendapatkan hasil yang optimal (Gatesoupe, 1999; Planas \& Cunha, 1999; Bentzon-Tilia et al., 2016; Giatsis et al., 2016). Tulisan ini bertujuan untuk memberikan ulasan mengenai peranan sistem gnotobiotik sebagai sarana untuk lebih memahami interaksi biota laut dan mikroorganismenya, serta potensi penerapannya pada budidaya biota laut, khususnya pada fase awal kehidupannya.

\section{INTERAKSI BIOTA LAUT- MIKROORGANISME}

Interaksi antara biota inang dan komunitas mikroorganisme pada biota akuatik dan terestrial mempunyai dua perbedaan mendasar, yaitu (1) waktu awal pemaparan (initial exposure period); dan (2) lingkungan/organ sebagai habitat dan tempat penempelan mikroorganisme. Biota terestrial umumnya pertama kali terpapar pada mikroorganisme setelah sistem pencernaannya berkembang, terutama setelah biota tersebut hidup secara independen di luar induknya. Sedangkan pada biota akuatik yang fertilisasinya berlangsung secara eksternal (di lingkungan perairan), paparan terhadap mikroorganisme terjadi sejak tahap awal perkembangan ontogenik-nya, yaitu pada saat saluran pencernaan maupun sistem imun berkembang sepenuhnya (Gatesoupe, 1999). Pada lingkungan terestrial, karakteristik kelembapan dan cairan yang ada pada saluran pencernaan merupakan faktor penentu kesukesan kolonisasi mikroorganisme. Sementara itu, biota akuatik menempati lingkungan yang sama (air), dan berbagi habitat dengan mikroorganisme. Hal ini menyebabkan mikroorganisme mempunyai preferensi penempelan pada organ-organ inangnya, mulai dari saluran pencernaan, insang, maupun kulit (Verschuere et al., 2000). Lingkungan akuatik juga mendukung mikroorganisme untuk hidup secara independen dari inangnya dan berkesempatan untuk tumbuh dan berkembang dalam jumlah yang besar di sekitar inang potensialnya. Proses invasi dan kolonisasi mikroorganisme pada biota akuatik berlangsung secara terus-menerus, baik melalui mulut, insang, maupun kulit (Verschuere et al., 2000). Pada biota laut seperti ikan, proses masuknya mirkoorganisme melalui mulut juga dipermudah karena mereka meminum air secara terus menerus untuk proses osmoregulatif (Gatesoupe, 1999).

Pada jenis-jenis ikan laut, mikroorganisme yang umumnya berkoloni di saluran pencernaan antara lain dari genera Aeromonas, Alcaligenes, Alteromonas, Carnobacterium, Flavobacterium, Micrococcus, Moraxella, Pseudomonas, dan Vibrio (Perez et al., 2010). Penempelan atau 
kolonisasi mikroorganisme ini dapat menyebabkan kerusakan pada lapisan epitel dan memicu inflamasi pada lapisan tersebut (Perez et al., 2010). Namun demikian, fitur-fitur yang bermanfaat bagi inang juga dapat diperoleh dari mikroorganisme yang secara alami hidup di lingkungan perairan, misalnya senyawa-senyawa antimikrobial yang dihasilkan oleh bakteri genus Lactococcus dan Carnobacterium dapat melindungi saluran pencernaan dari patogen (Nayak, 2010). Beberapa spesies mikroorganisme tersebut juga mengandung senyawa nutrien tambahan, dan berkompetisi dengan patogen lain untuk mendapatkan tempat penempelan pada membran mukosa inangnya (Nayak, 2010; Perez et al., 2010).

\begin{tabular}{llr}
\multicolumn{1}{c}{ Salah satu implementasi } \\
pemanfaatan interaksi inang- \\
mikroorganisme & adalah penggunaan \\
probiotik pada & kegiatan budidaya
\end{tabular}
biota laut. Menurut definisi dari FAO, probiotik adalah mikroorganisme yang mempunyai nilai manfaat apabila diberikan secara cukup kepada biota lain (Nayak, 2010; Akhter et al., 2015). Probiotik telah mulai digunakan dalam kegiatan budidaya sebagai pengganti obat-obatan kimia (antibiotik) yang dinilai tidak ramah lingkungan, maupun sebagai suplemen makanan untuk larva maupun biota dewasa (Gatesoupe, 1999; Vine et al., 2006; Nayak, 2010). Probiotik komersial biasanya ditambahkan pada pakan atau media (air) yang terdiri dari beberapa jenis mikroorganisme sekaligus. Penggunaan probiotik dinilai bermanfaat dalam beberapa aspek, antara lain peningkatan konversi pakan, pertumbuhan, dan manfaat kesehatan, terutama kemampuan untuk melindungi biota dari penyakit menular (Austin, 2015). Namun, pemakaian probiotik harus dilakukan secara rutin, atau dalam dosis yang tinggi melebihi jumlah komunitas mikroorganisme yang telah ada secara alami (Verschuere et al., 2000). Tingkat kesuksesan penggunaan probiotik juga sangat dipengaruhi oleh fenomena stokastik, dimana kondisi lingkungan dan inang pada waktu tertentu mempengaruhi perkembangan mikroorganisme yang terkandung pada produk probiotik komersial (Gatesoupe, 1999).

Untuk mengoptimalkan fungsi dan aplikasi probiotik pada kegiatan budidaya, diperlukan informasi yang akurat mengenai seleksi spesies probiotik, metode pemberian, maupun dosisnya. Manipulasi mikroorganisme yang berhabitat di dalam tubuh biota tanpa mengubah homeostasis sistem metabolisme biota itu sendiri memerlukan pengetahuan mendalam mengenai interaksi mikroorganisme dan inangnya untuk mendapatkan strategi yang tepat dalam merangsang imunitas lokal maupun sistemik (Nayak, 2010). Salah satu strategi kunci dalam mempelajari interaksi ini adalah bagaimana mendefinisikan fungsi dan metabolisme biota pada lingkungan yang bebas dari mikroorganisme, dan mengevaluasi pengaruh dari penambahan satu atau lebih populasi mikroorganisme yang telah diketahui (Marques et al., 2006). 


\section{MENGENAL AKSENIK DAN GNOTOBIOTIK}

Salah satu "tools" yang potensial mengungkap peranan dan interaksi inang/mikroorganisme adalah sistem gnotobiotik (Marques et al., 2006; Pham et al., 2008; Giatsis et al., 2014). Secara etimologi, gnotobiotik (EN: gnotobiotic) berasal dari bahasa latin "gnosis" yang berarti pengetahuan dan "bios" yang berarti hidup. Trexler (1978) mendefinisikan gnotobiotik sebagai "Bidang penelitian yang menitikberatkan pada pemeliharaan makhluk hidup secara sendiri, atau bersama dengan organisme lain yang diketahui secara keseluruhan". Dalam perkembangannya, istilah gnotobiotik dapat diartikan sebagai "Sistem eksperimental pemeliharaan biota dimana semua mikroorganisme telah diketahui, atau telah dihilangkan" (Pham et al., 2008). Prinsip dasar eksperimen gnotobiotik terdiri dari dua tahapan utama, yaitu (1) kemampuan untuk memelihara atau menumbuhkan biota yang bebas dari segala jenis mikroorganisme. Fase ini diistilahkan sebagai "aksenik" (EN: axenic), yang berasal dari istilah latin $a$ - (tanpa), dan xenos (asing); dan (2) fase kolonisasi, dimana pada saluran pencernaan biota aksenik diberikan input berupa satu atau lebih mikroorganisme yang sebelumnya telah diketahui spesies dan/atau fungsinya (Pham et al., 2008).

Marques et al. (2006) menjelaskan hambatan untuk melakukan eksperimen dengan sistem gnotobiotik, antara lain: (1) kompleksitas teknis dan tingginya biaya untuk mengkondisikan lingkungan, pakan, maupun sarana penelitian; (2) kemampuan khusus yang diperlukan untuk menangani dan menjaga biota agar bebas dari kontaminasi; (3) kesulitan untuk meniru kondisi alami lingkungan yang bervariasi dan kompleks pada skala laboratorium; dan (4) karakteristik intrinsik pada biota aksenik itu sendiri.

Menurut Pham et al. (2008), biota gnotobiotikbermanfaatuntukmempelajari bagaimana kolonisasi mikroorganisme memengaruhi berbagai macam proses biologis, termasuk di dalamnya ekspresi gen, fisiologis, imunitas, dan daur hidup. Eksperimen dengan meng-ekspos biota aksenik dalam media atau pakan yang mengandung spesies mikroorganisme (yang telah diketahui) pada periode tertentu dalam siklus hidupnya, dapat berguna untuk mengungkap proses, mekanisme aksi (mechanism of action), dan respons biologis yang terjadi. Selain itu, biota gnotobiotik adalah sarana yang baik untuk mempelajari interaksi antar mikroorganisme yang terjadi dalam konteks fisiologis pada inang yang hidup, sehingga perubahan spesies mikroorganisme dan komunitas mikroorganisme di dalam tubuh inang dapat dipelajari dan diamati seiring waktu menggunakan teknologi genomik terkini seperti sekuensing DNA. Interaksi antara inang-mikroorganisme maupun antar mikroorganisme itu sendiri dapat dianalisis sebagai perpaduan hubungan (function) dari genotipe mikroorganisme, komposisi mikroorganisme, genotipe inang, tahap perkembangan inang, patobiologi inang, kolonisasi mikroorganisme, lokasi anatomis, 
maupun parameter lingkungan dan fisiologis lainnya.

\section{PROTOKOL SISTEM AKSENIK- GNOTOBIOTIK}

Beberapa studi mengenai metode mendapatkan biota laut gnotobiotik telah dilakukan dan dipublikasikan. Tulisan ini akan menitik beratkan pada jenis vertebrata laut yang mempunyai nilai ekonomis penting dan/atau telah dibudidayakan secara komersil, yaitu ikan kod Atlantik (Gadus morhua), dan ikan kakap laut Eropa / European sea bass (Dicentrarchus labrax). Kedua biota laut tersebut telah berhasil dipelihara dalam sistem gnotobiotik, masing-masing oleh Forberg et al. (2011), dan Dierckens et al. (2009).

Secara umum, biota laut aksenik dapat diperoleh melalui tiga prosedur, yaitu: (1) pembedahan/pengambilan langsung telur, embrio, atau larva yang belum terkontaminasi mikroorganisme dari perut induknya; (2) menggunakan antibiotik untuk mengurangi kontaminasi pada telur, larva atau embrio yang telah dibuahi, kemudian menambah perlakuan dengan larutan antibiotik kuat untuk menghilangkan mikroorganisme yang tersisa, dan (3) menggunakan telur, larva, atau embrio konvensional yang sebelumnya telah melalui beberapa kali pencucian untuk mengurangi level kontaminasi, dilanjutkan dengan perlakuan antibiotik atau senyawa kimia untuk menghilangkan mikroorganisme secara keseluruhan (Marques et al., 2006).
Biota aksenik pada larva ikan cod Atlantik (Gadus morhua) diperoleh dengan melakukan keseluruhan eksperimen di lingkungan steril dalam lemari laminar-flow, dimana telur yang telah dibuahi kemudian diinkubasi pada botol Nalgene volume $2 \mathrm{~L}$ berisi air laut yang telah dilewatkan pada filter $0.22 \mu \mathrm{m}$ dan di-autoclave $\left(121^{\circ} \backslash \mathrm{C}, 20\right.$ menit) (Gambar 1). Setelah menetas, larva tetap dipelihara di dalam botol yang sama tanpa aerasi, dan diberi pakan berupa rotifer aksenik jenis Brachionus sp. Kultur rotifer ini juga dilakukan dalam kondisi aksenik dengan diberikan pakan berupa alga Isochrysis sp. Rotifer Brachionus sp. yang telah menetas didisinfeksi menggunakan larutan antibiotik rifampicin dan ampicilin (10 ppm) untuk mempertahankan kondisi aksenik-nya. Setelah larva ikan kod aksenik berumur 14 hari, tiga spesies bakteri kultur murni Microbacterium ND 2-7, Pseudoalteromonas RA 7-14, dan Vibrio anguillarum HI610, diberikan pada masing-masing media pemeliharaan larva ikan kod Atlantik dengan konsentrasi $10^{6}$ sel ml-1 (Forberg et al., 2011). 


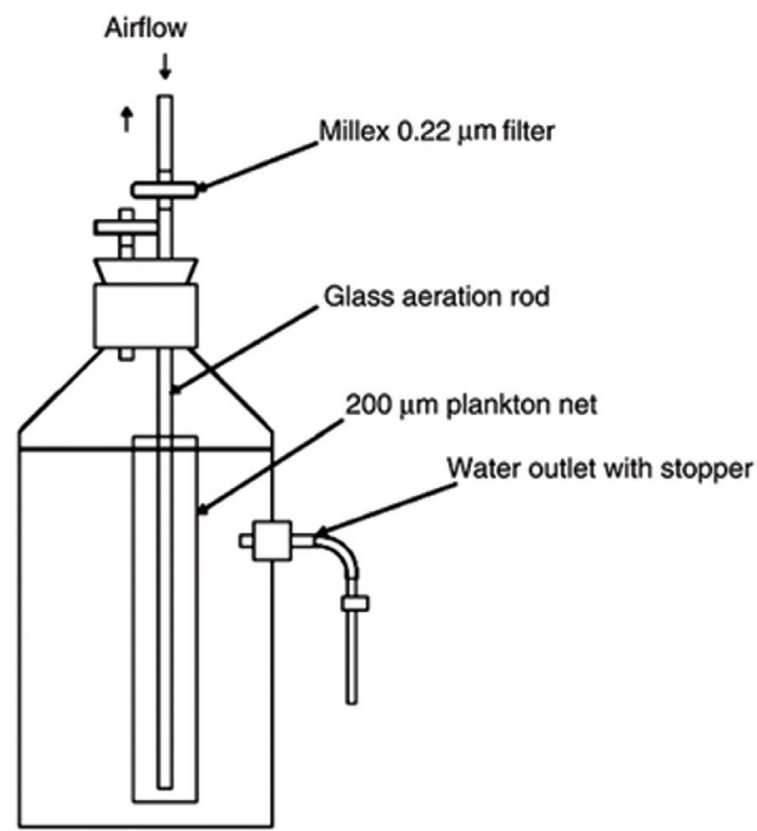

Gambar 1. Sistem eksperimen gnotobiotik menggunakan botol nalgene (vol. 21) yang dilengkapi dengan sistem pemberian pakan dan aerasi yang steril (Forberg, et al., 2011)

Pada ikan kakap laut eropa (Dicentrarchus labrax), Dierckens et al. (2009) menggunakan glutaraldehyde sebagai agen disinfeksi pada telur ikan yang telah dibuahi untuk menghilangkan mikroorganisme yang ada. Telur berumur 2 hari pascapembuahan direndam dalam larutan $100 \mathrm{mg} \mathrm{l}^{-1}$ glutaraldehyde selama 3 menit pada suhu $16^{\circ} \mathrm{C}$, dan kemudian diinkubasi dalam larutan antibiotik rifampicin dan ampicilin dengan konsentrasi masing-masing 10

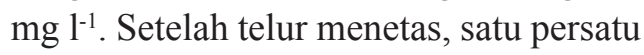
larva dipindahkan ke dalam botol (vial) berukuran $15 \mathrm{ml}$ berisi air laut steril dan larutan antibiotik rifampicin $10 \mathrm{mg}$ $1^{-1}$ yang ditempatkan pada rotor elektrik yang bergerak dengan kecepatan $4 \mathrm{rpm}$. Eksperimen gnotobiotik dilakukan pada hari ke-3 setelah larva menetas. Tiga strain bakteri yang digunakan yaitu: Aeromonas hydrophila (LVS3), Vibrio (Listonella) anguillarum serovar O1, dan $V$. (L) anguillarum serovar $\mathrm{O} 2 \mathrm{a}$ dengan cara menambahkan konsentrat masing-masing strain bakteri pada botol pemeliharaan larva sebesar $10^{5} \mathrm{cfu}$. $\mathrm{ml}^{-1}$. Pada hari ke-7 setelah penetasan larva, setiap dua hari sekali dilakukan penambahan 35 individu nauplii Artemia sp. aksenik sebagai pakan pada masingmasing botol pemeliharaan.

Faktor-faktor yang mempengaruhi kesuksesan protokol eksperimen aksenikgnotobiotik antara lain jenis dan volume disinfektan; wadah/tempat pemeliharaan yang steril; dan penambahan pakan. Pada studi gnotobiotik biota laut, glutardehyde 
$\left(\mathrm{C}_{5} \mathrm{H}_{8} \mathrm{O}_{2}\right)$ menjadi salah satu senyawa disinfektan yang umum digunakan pada telur. Sedangkan antibiotik/antimikrobial berspektrum luas banyak digunakan untuk menghilangkan mikroorganisme dan kontaminan lainnya pada larva (Tabel 1).

Tabel 1. Jenis disinfektan dan antimikrobial yang umum digunakan dalam sistem aksenik-gnotobiotik biota laut (de Swaef et al., 2015).

\begin{tabular}{|l|l|l|l|}
\hline $\begin{array}{c}\text { Nama Disinfektan dan } \\
\text { Antimikrobial }\end{array}$ & \multicolumn{1}{|c|}{ Fungsi } & Target & \multicolumn{1}{|c|}{ Jenis biota } \\
\hline Hidrogen peroksida $\left(\mathrm{H}_{2} \mathrm{O}_{2}\right)$ & $\begin{array}{l}\text { Biosida } \\
\text { (Oksidator kuat) }\end{array}$ & Telur & Gadus morhua, Sparus aurata \\
\hline Bronopol $\left(\mathrm{C}_{3} \mathrm{H}_{6} \mathrm{BrNO}_{4}\right)$ & $\begin{array}{l}\text { Biosida } \\
\text { spektrum luas }\end{array}$ & Telur & $\begin{array}{l}\text { G. morhua, Hippoglossus } \\
\text { hippoglossus }\end{array}$ \\
\hline Glutardehyde $\left(\mathrm{C}_{5} \mathrm{H}_{8} \mathrm{O}_{2}\right)$ & $\begin{array}{l}\text { Biosida dan } \\
\text { antifungal }\end{array}$ & Telur & G. morhua, Dicentrarchus labrax \\
\hline Ozon $\left(\mathrm{O}_{3}\right)$ & $\begin{array}{l}\text { Biosida } \\
\text { (Oksidator kuat })\end{array}$ & Telur & D. labrax, Dentex dentex, S. aurata \\
\hline Rifampicin & $\begin{array}{l}\text { Antibiotik } \\
\text { spektrum luas }\end{array}$ & $\begin{array}{l}\text { Telur dan } \\
\text { larva }\end{array}$ & D. labrax, G. morhua \\
\hline Ampicilin & $\begin{array}{l}\text { Antibiotik } \\
\text { spektrum luas }\end{array}$ & $\begin{array}{l}\text { Telur dan } \\
\text { larva }\end{array}$ & D. labrax, G. morhua \\
\hline
\end{tabular}

\section{VERIFIKASI AKSENIK- GNOTOBIOTIK}

Metode verifikasi yang akurat diperlukan untuk memastikan kondisi aksenik dan gnotobiotik telah dicapai. Verifikasi kondisi aksenik dapat dilakukan dengan dua cara utama, yaitu : (1) kultur bakteri pada media (agar dan kaldu), baik yang umum maupun media bernutrisi khusus untuk menumbuhkan mikroorganisme tertentu; dan (2) pengamatan mikroskopis dengan menggunakan pewarnaan khusus, seperti acridine orange, aminofluorescein, dan garam tetrazolium untuk mendeteksi mikroorganisme yang tidak dapat tumbuh pada media buatan (Marques et al., 2006). Selain pada sampel biota, verifikasi kondisi aksenik juga dapat dilakukan pada media pemeliharaan dengan melewatkan sampel media yang telah diberi pewarnaan pada sistem flow-cytometer untuk melihat adanya mikroorganisme yang tumbuh berdasarkan jumlah partikel yang dapat menyerap pewarnaan (Schaeck et al., 2016).

Verifikasi sistem gnotobiotik pada prinsipnya memerlukan metode yang dapat membedakan antara kontaminan dan mikroorganisme yang telah diketahui/diperkenalkan (Trexler, 1978). Saat ini, biologi molekuler adalah salah satu metode spesifik yang dapat membedakan antara mikroorganisme yang diperkenalkan pada biota aksenik, dan mengeliminasi kemungkinan kontaminasi mikroorganisme asing. Salah satu penerapannya yaitu dengan teknik 
Denaturing Gradient Gel Electrophoresis (DGGE) hasil fragmen Polymerase Chain Reaction (PCR) pada sampel yang dihasilkan dengan primer universal (16 rDNA dan 16 rRNA) (Marques et al., 2006). Teknik lanjutan untuk mengetahui jenis mikroorganisme antara lain dengan pengurutan/sequencing DNA dari sampel yang telah dianalisis, atau dengan kultur bakteri yang telah diketahui menggunakan media kultur yang spesifik (Pham et al., 2008; Giatsis et al., 2015).

Tantangan utama dari metode verifikasi pada sistem gnotobiotik yaitu tingginya kemungkinan hasil false positive maupun false negative pada analisis sampel biota maupun medianya. Pham et al. (2008) menjelaskan bahwa teknik identifikasi bakteri melalui amplifikasi DNA menggunakan 16 rRNA mempunyai potensi untuk menghasilkan false-positive karena adanya asam nukleat bebas yang dapat terdeteksi bahkan jika mikroorganisme yang hidup tidak ditemukan. Adapun hasil false-negative dapat ditemukan pada teknik pewarnaan pada kultur bakteri dikarenakan jumlah sampel yang sedikit atau volume sampel yang tidak mencukupi.

\section{STUDI GNOTOBIOTIK PADA BIOTA LAUT}

Secara umum, studi yang menggunakan sistem gnotobiotik pada biota akuatik masih cukup terbatas, berbeda dengan studi yang sama pada biota terestrial yang telah banyak mengalami kemajuan sejak tahun 1950-an sampai sekarang (Marques et al., 2006). Pada biota air tawar, studi gnotobiotik pada ikan zebra (Danio rerio) telah dilakukan dengan cukup lengkap dan menjadi model rujukan (Rawls et al., 2004; Pham et al., 2008). Sedangkan pada biota laut, studi yang ekstensif telah dilakukan pada ikan kod atlantik (Gadus morhua), dan ikan kakap laut Eropa/Sea bass (Dicentrarchus labrax) (Dierckens et al., 2009; Reckeki et al., 2009; Forberg et al., 2011).

Pada ikan kod atlantik (Gadus morhua), studi yang dilakukan oleh Forberg et al. (2011) merupakan kali pertama berhasilnya protokol gnotobiotik pada larva ikan tersebut, sekaligus protokol gnotobiotik pertama pada larva ikan laut tanpa penggunaan antibiotik secara terus-menerus. Tingkat penetasan telur (hatching rate) yang dihasilkan pada kondisi aksenik mencapai 90\%, dengan sintasan mencapai lebih dari $60 \%$ sebelum memasuki fase gnotobiotik. Penambahan tiga spesies bakteri (Microbacterium sp., Pseudoalteromonas sp., dan Vibrio anguillarum) yang dilakukan pada hari ke-3 sampai hari ke-9 setelah penetasan menghasilkan sintasan rata-rata mencapai $50 \%$, kecuali pada perlakuan dengan bakteri $V$. anguillarum dimana terjadi mortalitas mencapai $100 \%$. Studi ini menyimpulkan bahwa kolonisasi bakteri pada larva aksenik ikan kod Atlantik berhubungan erat dengan kemampuan bakteri untuk berkompetisi di dalam saluran pencernaan, yang dipengaruhi oleh periode pembelahan (generation time) dan aktivitas metabolik pada strain bakteri tersebut. Penelitian gnotobiotik lanjutan pada larva ikan kod atlantik oleh Forberg \& Vadstein (2013) mampu mengidentifikasi 10 ekspresi gen spesifik 
yang diregulasi oleh bakteri tertentu. Ekspresi gen tersebut berasosiasi dengan proses-proses metabolik biota seperti penyerapan nutrien dan respons imun.

Penelitian yang dilakukan oleh Dierckens et al. (2009) merupakan studi aksenik-gnotobiotik pertama pada larva ikan kakap laut Eropa (Dicentrarchus labrax) yang melibatkan biota aksenik pada rantai makanan larva (Artemia sp.). Pada fase aksenik, hasil dari dua eksperimen independen menunjukkan sintasan mencapai masing-masing $67,4 \%$ (pada hari ke-12), dan 97,11\% (pada hari ke-11). Hasil pada fase gnotobiotik yang dimulai pada hari ke-3 - 12 setelah penetasan larva menunjukkan sintasan terendah yaitu 3,1\% (Hari ke-11, jenis mikroorganisme Vibrio anguillarum O2a), dan yang tertinggi yaitu 68,4\% (Hari ke-12, jenis mikroorganisme Aeromonas hydrophilla). Secara khusus, penelitian ini berhasil merumuskan protokol aksenik yang berhasil menghilangkan keseluruhan mikroorganisme pada telur dan larva, baik dengan verifikasi melalui kultur bakteri konvensional, maupun uji genomik (amplifikasi dan analisis DNARNA).

\section{STUDI GNOTOBIOTIK PADA BIOTA LAUT DI MASA MENDATANG}

Penelitian dengan sistem gnotobiotik pada biota laut tidak dapat dilepaskan dari fungsi utamanya sebagai sistem uji dan eksperimentasi untuk mengungkap interaksi mikroorganisme dan inangnya. Penggabungan antara sistem gnotobiotik dengan pengetahuan dan teknologi terkini lainnya berpotensi memberikan pandangan yang lebih akurat mengenai beberapa fenomena yang belum terdeskripsi secara menyeluruh, antara lain: (1) mekanisme kolonisasi mikroorganisme dan pengaruhnya bagi tumbuh dan berkembangnya probiotik pada saluran pencernaan larva; (2) ekspresi gen dan kaitannya dengan proses metabolisme pada biota laut; (3) mekanisme kompetisi dan senyawa antimikrobial pada strain probiotik biota laut; (4) evaluasi pengaruh racun atau biota yang terpapar radiasi; (5) evaluasi pengaruh asupan nutrisi eksternal (pakan) pada larva biota laut; dan potensi-potensi penerapan gnotobiotik lainnya pada bidang biologi laut (Giatsis et al., 2016; Hai, 2015; Marques et al., 2006).

Evaluasi terhadap protokol untuk memperoleh kondisi aksenik-gnotobiotik perlu untuk terus dilakukan. Minimalisasi penggunaan senyawa kimia berbahaya seperti antibiotik dan anti-fungal juga menjadi perhatian untuk mengurangi risiko abnormalitas dan mortalitas biota uji (Forberg et al., 2011). Selain itu, semakin berkembangnya teknologi genomik maupun kultur bakteri juga dapat menjadi peluang untuk merumuskan protokol verifikasi aksenik-gnotobiotik yang lebih reproduktif, efektif, dan akurat (Schaeck et al., 2016). 


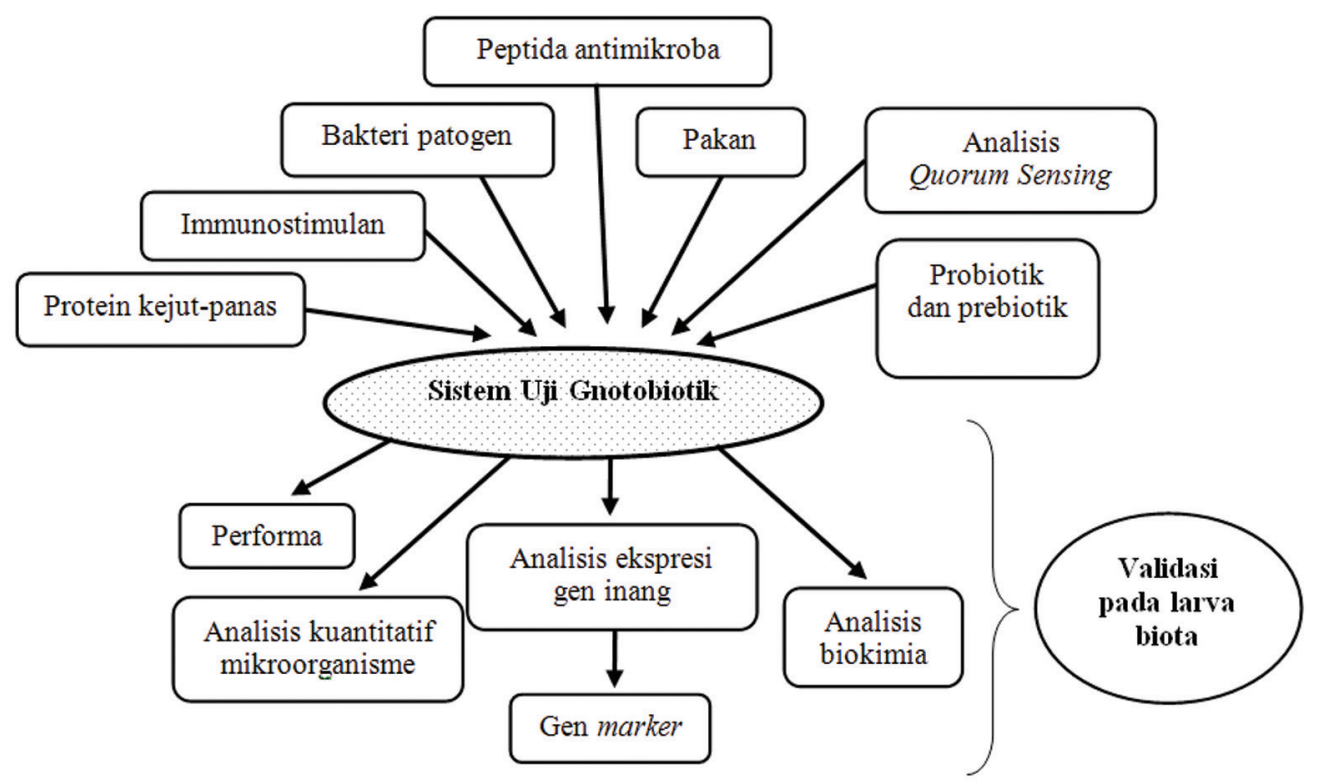

Gambar 2. Skema representasi riset gnotobiotik di masa mendatang (Marques et al., 2006)

Teknologi budidaya, jenis biota, kondisi lingkungan, maupun jenis mikroorganisme pada berbagai kawasan laut berpotensi besar bagi pemanfaatan mikroorganisme pada budidaya biota laut, terutama dengan beralihnya paradigma penggunaan antibiotik dan obat-obatan kimia ke probiotik dan prebiotik (Perez et al., 2008). Penggunaan probiotik yang spesifik pada biota budidaya merupakan peluang bagi berkembangnya gnotobiotik sebagai sistem uji dan model untuk mempelajari mekanisme kerja probiotik pada larva biota tertentu, khususnya untuk mengetahui dinamikanya pada rantai makanan (Tinh et al., 2008). Selain itu, Vadstein et al. (2013) menjelaskan bahwa salah satu kunci untuk mengoptimalkan pengaruh komponen pakan dan metode pemberiannya pada hatchery budidaya yaitu dengan penelitian menggunakan pakan yang dimurnikan (purified diets) dikombinasikan dengan sistem gnotobiotik.

Marques et al. (2006) merangkum peluang riset gnotobiotik di masa mendatang dalam satu skema yang menunjukkan berbagai input dan paradigma ilmu dan teknologi saat ini yang dapat digabungkan atau diaplikasikan dengan sistem gnotobiotik (Gambar 2). Skema ini juga merangkum beberapa fenomena dan permasalahan pada biologi dan ekologi biota laut yang dapat diuraikan dengan mengacu pada hasil analisis eksperimen gnotobiotik. Dengan demikian, penggunaan sistem gnotobiotik pada biota laut di masa mendatang dimungkinkan akan meningkat dan lebih variatif sesuai dengan bidang yang diteliti dan teknologi yang digunakan. 


\section{PENUTUP}

Usaha budidaya laut yang terus berkembang menuntut adanya pasokan telur maupun larva biota budidaya yang berkualitas dan berkelanjutan. Untuk itu diperlukan teknologi hatchery yang mampu mengoptimalkan tingkat penetasan telur (hatching rate), tingkat pertumbuhan, maupun sintasan larva. Peluang memanfaatkan sistem gnotobiotik pada biota laut untuk mendukung kegiatan budidaya laut di Indonesia masih sangat terbuka, terutama pada biota yang memiliki teknologi hatchery dengan sintasan dan pertumbuhan relatif rendah, seperti jenis-jenis kerapu (Epinephelus sp.), kepiting (Scylla sp.), maupun teripang (Holothuria sp.). Tersedianya protokol aksenik-gnotobiotik yang efektif dengan metode verifikasi yang terus berkembang memungkinkan segenap institusi pendidikan tinggi maupun lembaga penelitian di Indonesia untuk melakukan studi gnotobiotik dalam rangka meningkatkan produksi dan daya saing budidaya laut kita di masa mendatang.

\section{PUSTAKA}

Akhter, N., B. Wu, A. M. Memon and M. Mohsin. 2015. Probiotics and prebiotics associated with aquaculture: a review. Fish \& shellfish immunology, 45: 733741.

Attramadal, K. J., I. Salvesen, R. Xue, G. Øie, T. R. Størseth, O. Vadstein and Y. Olsen. 2012. Recirculation as a possible microbial control strategy in the production of marine larvae. Aquacultural engineering, 46: 27-39.

Austin, B. 2015. Editorial: Probiotics. Fish \& Shellfish Immunology, 45: 1 .

Bentzon-Tilia, M., E. C. Sonnenschein and L. Gram. 2016. Monitoring and managing microbes in aquaculture-Towards a sustainable industry. Microbial biotechnology, 9: 576-584.

De Swaef, E., W. van den Broeck, K. Dierckens and A. Decostere. 2016. Disinfection of teleost eggs: a review. Reviews in Aquaculture, 8: 321-341.

Dierckens, K., A. Rekecki, S. Laureau, P. Sorgeloos, N. Boon, W. van den Broeck and P. Bossier. 2009. Development of a bacterial challenge test for gnotobiotic sea bass (Dicentrarchus labrax) larvae. Environmental microbiology, 11: 526-533.

Forberg, T., A. Arukwe and O. Vadstein. 2011. A protocol and cultivation system for gnotobiotic Atlantic cod larvae (Gadus morhua L.) as a tool to study host microbe interactions. Aquaculture, 315: 222-227.

Forberg, T. and O. Vadstein. 2013. Lessons learned from gnotobiotic systems on the effect of bacteria on growth, survival, and gene expression in marine larvae. larvi 2013: 129. 
Gatesoupe, F. 1999. The use of probiotics in aquaculture. Aquaculture, 180: 147-165.

Giatsis, C., D. Sipkema, H. Smidt, J. Verreth and M. Verdegem. 2014. The Colonization Dynamics of the Gut Microbiota in Tilapia Larvae. PLOS ONE, 9: e103641.

Giatsis, C., D. Sipkema, H. Smidt, H. Heilig, G. Benvenuti, J. Verreth and M. Verdegem. 2015. The impact of rearing environment on the development of gut microbiota in tilapia larvae. Scientific Reports, 5: 18206.

Giatsis, C., D. Sipkema, J. RamiroGarcia, G. M. Bacanu, J. Abernathy, J. Verreth, H. Smidt and M. Verdegem. 2016. Probiotic legacy effects on gut microbial assembly in tilapia larvae. Scientific Reports, 6: 33965 .

Hai, N. 2015. The use of probiotics in aquaculture. Journal of applied microbiology, 119: 917-935.

Marques, A., F. Ollevier, W. Verstraete, P. Sorgeloos and P. Bossier. 2006. Gnotobiotically grown aquatic animals: opportunities to investigate host-microbe interactions. Journal of applied microbiology, 100: 903-918.

Nayak, S. 2010. Probiotics and immunity: a fish perspective. Fish \& shellfish immunology, 29: 2-14.
Pérez, T., J. Balcázar, I. Ruiz-Zarzuela, N. Halaihel, D. Vendrell, I. De Blas and J. Múzquiz. 2010. Hostmicrobiota interactions within the fish intestinal ecosystem. Mucosal immunology 3: 355360 .

Pham, L. N., M. Kanther, I. Semova and J. F. Rawls. 2008. Methods for generating and colonizing gnotobiotic zebrafish. Nature protocols, 3: 1862-1875.

Planas, M. and I. Cunha. 1999. Larviculture of marine fish: problems and perspectives. Aquaculture, 177: 171-190.

Rawls, J. F., B. S. Samuel and J. I. Gordon. 2004. Gnotobiotic zebrafish reveal evolutionarily conserved responses to the gut microbiota. Proceedings of the National Academy of Sciences of the United States of America, 101: 4596-4601.

Rekecki, A., K. Dierckens, S. Laureau, N. Boon, P. Bossier and W. van den Broeck. 2009. Effect of germ-free rearing environment on gut development of larval sea bass (Dicentrarchus labrax L.). Aquaculture, 293: 8-15.

Schaeck, M., E. De Swaef, W. van den Broeck, S. van Nevel, N. Boon, N. De Geyter, R. Morent, K. Demeestere, L. Duchateau and C. Coulombet. 2016. Germ-free sea bass Dicentrarchus labrax larval model: a valuable tool 
in the study of host-microbe interactions. Diseases of aquatic organisms, 117: 177185.

Tinh, N. T. N., K. Dierckens, P. Sorgeloos and P. Bossier. 2008. A review of the functionality of probiotics in the larviculture food chain. Marine Biotechnology, 10: $1-12$.

Trexler, P. 1978. A rationale for the development of gnotobiotics. Laboratory animals, 12: 257262.

Vadstein, O., Ø. Bergh, F. J. Gatesoupe, J. Galindo-Villegas, V. Mulero, S. Picchietti, G. Scapigliati, P. Makridis, Y. Olsen and K. Dierckens. 2013. Microbiology and immunology of fish larvae. Reviews in Aquaculture, 5: $1-25$.
Verschuere, L., G. Rombaut, P. Sorgeloos and W. Verstraete. 2000. Probiotic bacteria as biological control agents in aquaculture. Microbiology and molecular biology reviews, 64: 655-671.

Vine, N. G., W. D. Leukes and H. Kaiser. 2006. Probiotics in marine larviculture. FEMS microbiology reviews, 30: 404427. 